\title{
Protein Carriers for Glycoconjugate Vaccines: History, Selection Criteria, Characterization and New Trends
}

\author{
Francesca Micoli ${ }^{1}$, Roberto Adamo 2 (iD) and Paolo Costantino ${ }^{2, *}$ \\ 1 GSK Vaccines Institute for Global Health (GVGH), 53100 Siena, Italy; francesca.x.micoli@gsk.com \\ 2 GSK, 53100 Siena, Italy; roberto.x.adamo@gsk.com \\ * Correspondence: paolo.x.costantino@gsk.com; Tel.: +39-0577-243324
}

Received: 22 May 2018; Accepted: 13 June 2018; Published: 15 June 2018

\begin{abstract}
Currently licensed glycoconjugate vaccines are composed of a carbohydrate moiety covalently linked to a protein carrier. Polysaccharides are T-cell independent antigens able to directly stimulate B cells to produce antibodies. Disease burden caused by polysaccharide-encapsulated bacteria is highest in the first year of life, where plain polysaccharides are not generally immunogenic, limiting their use as vaccines. This limitation has been overcome by covalent coupling carbohydrate antigens to proteins that provide $\mathrm{T}$ cell epitopes. In addition to the protein carriers currently used in licensed glycoconjugate vaccines, there is a search for new protein carriers driven by several considerations: (i) concerns that pre-exposure or co-exposure to a given carrier can lead to immune interference and reduction of the anti-carbohydrate immune response; (ii) increasing interest to explore the dual role of proteins as carrier and protective antigen; and (iii) new ways to present carbohydrates antigens to the immune system. Protein carriers can be directly coupled to activated glycans or derivatized to introduce functional groups for subsequent conjugation. Proteins can be genetically modified to pre-determine the site of glycans attachment by insertion of unnatural amino acids bearing specific functional groups, or glycosylation consensus sequences for in vivo expression of the glycoconjugate. A large portion of the new protein carriers under investigation are recombinant ones, but more complex systems such as Outer Membrane Vesicles and other nanoparticles are being investigated. Selection criteria for new protein carriers are based on several aspects including safety, manufacturability, stability, reactivity toward conjugation, and preclinical evidence of immunogenicity of corresponding glycoconjugates. Characterization panels of protein carriers include tests before conjugation, after derivatization when applicable, and after conjugation. Glycoconjugate vaccines based on non-covalent association of carrier systems to carbohydrates are being investigated with promising results in animal models. The ability of these systems to convert T-independent carbohydrate antigens into T-dependent ones, in comparison to traditional glycoconjugates, needs to be assessed in humans.
\end{abstract}

Keywords: glycoconjugate vaccines; protein carriers; characterization

\section{Introduction}

In the 1980s, glycoconjugate vaccines were introduced into the arsenal of available weapons for prevention of infectious diseases to overcome an important limitation of conventional polysaccharide (PS) vaccines [1]. Despite PS vaccines being immunogenic and protective in adults against serious infectious diseases, such as meningitis and pneumonia, they are not efficacious in the first years of life when the disease burden caused by many encapsulated bacteria is high [2-4]. PS are defined as T-cell independent antigens which can directly stimulate B cells to produce antibodies. They are made up of repetitive structures containing $B$ cells but not $T$ cell epitopes, the latter being essential to engage $\mathrm{T}$ cells and trigger a B-T cooperation, leading to a more complete immune response at any 
age $[5,6]$. Chemical conjugation of PS or oligosaccharide antigens to proteins results in vaccines where the protein moiety provides $\mathrm{T}$ cell epitopes [7]. While there are many reports on the preparation and characterization of glycoconjugate vaccines focusing on the glycan moiety, less attention has been put on aspects related to the protein carrier. Here, we provide an overview of the carriers for glycoconjugate vaccines, including traditional and more recently used recombinant proteins, exploited in some examples with the additional role of antigen. Novel carrier systems, such as inorganic nanoparticles, virus-like particles and Outer Membrane Vesicles (OMVs) are also presented. The role of protein carrier, conjugation chemistries, selection criteria, and characterization before and after conjugation are discussed. Relevant aspects related to the impact of the carrier protein and the conjugation degree on the immune response of glycoconjugate vaccines, which need to be further investigated in humans, are here analyzed.

\section{The Concept of Hapten and Carrier}

In early 20th century, Karl Landsteiner demonstrated that the specificity of the immune response to proteins (carriers) was changed when small molecules (haptens) are chemically attached to them. In particular, he found that antibodies were induced against new determinants comprising the conjugated small molecule. More interestingly, these antibodies recognized the hapten also in its native not conjugated form [8]. Later, Avery and Goebel published papers showing that the "chemical union" of small saccharides to proteins results in enhanced immunogenicity of the saccharide and that saccharide specific antibody concentrations increase after reinjection of the conjugate [9]. This series of papers culminated with the demonstration that, when the capsular PS of type III pneumococcus is conjugated to protein and then inoculated in rabbits, the rabbits produce anti-pneumococcus III specific antibodies which protect them from the challenge with a virulent pneumococcal type III strain [10].

\section{Polysaccharide Based Vaccines}

The history of PS based vaccines started with the research on vaccines against pneumococcus, focused on capsular PS decorating the surface of this pathogen. In 1932, Sutliff reported the first evidence that "protein free" preparations of pneumococcal PS elicit specific antibody titers with anti-pneumococcal power in subjects ranging in age from 15 to 56 years [11]. In 1945, the first tetravalent anti-pneumococcal vaccine was available [12].

At the same time, the introduction of antibiotics for treatments of bacterial diseases slowed down the development of PS vaccines. However, it was soon clear that antimicrobial treatment, even if successful, could not be the only solution due to treatment failures, frequent serious sequelae in subjects recovering from diseases such as meningitis, and the emergence of antimicrobial resistant strains.

In 1978, a quadrivalent vaccine based on meningococcal serogroups A, C, W and Y PS was licensed, and three years later it was the turn of a 23-valent anti-pneumococcal PS vaccine, followed by the anti-Haemophilus influenzae type b (Hib) PS vaccine in 1985.

\section{From Polysaccharide Vaccines to Glycoconjugate Vaccines}

The clinical trials carried out during the development of meningococcal and Haemophilus influenzae type $b$ PS vaccines showed that the efficacy in children below two years of age was very low [2]. Similar observation was done for pneumococcal PS vaccines, although with differences depending on the serotype [3], confirming some evidences already available [4]. This was a trigger point for the research and the development of glycoconjugate vaccines. The concept of carrier/hapten introduced by the works of Landsteiner, Avery and Goebel was taken up again.

The first preclinical and clinical reports on glycoconjugate vaccines were those describing Hib PS-protein conjugates by the team of John Robbins at NIH [1]. Thanks to this pioneering work, the first glycoconjugate vaccines against Hib were licensed between 1987 and 1990. At the same time, active research started in academic and industrial settings to develop conjugate vaccines against the most 
epidemiological relevant serotypes of pneumococcus and meningococcus, leading to licensure of many other glycoconjugate vaccines [13].

\section{Mechanism of Action of Glycoconjugate Vaccines}

PS are T-cell independent antigens capable of directly stimulating B-cell differentiation into plasma cells (which produce antibodies) by cross-linking B-cell receptors (BCR). This mechanism is not yet mature in infants where cooperation between $B$ and $T$ cells is required for efficient immune responses to PS immunogens $[14,15]$. In glycoconjugates, the protein carrier provides the T epitopes for T-cell help recruiting, while the B epitopes for PS specific B cells engagement are provided by the saccharide moiety. The latter binds to BCR and, after internalization, B cells direct the processing of the protein moiety of glycoconjugate in peptides that are presented to carrier specific $\mathrm{T}$ cells in association with major histocompatibility complex (MHC) class II molecules. When B cells receive T cell help, they proliferate and differentiate into plasma cells producing antibodies, with class switching particularly to IgG, and into memory B cells. The latter ones, on subsequent encounter of specific antigen, can rapidly proliferate and differentiate into plasma cells, producing high antibody titers. Antibody avidity is increased through affinity maturation in germinal centers [5]. Recently, based on studies with GBSIII-protein conjugates, an additional mechanism has been proposed according to which the glycoconjugate is processed into glycan-peptides inside PS specific B cells. The resulting glycan-peptides bind MHC class II via the peptide portion allowing the glycan moiety to be exposed and recognized by the $\mathrm{T}$-cell receptor of carbohydrate specific $\mathrm{T}$ cell clones which then provide the cognate help to B cells [16]. According to these mechanisms, a conjugate vaccine can induce a T-cell-dependent response and be immunogenic from early infancy. It is worth of mentioning that an immunogenic response against carbohydrates has also been achieved by using glycolipid carriers, such as $\alpha$-Galactosyl ceramide [17] or synthetic lipid A derivatives [18], via activation of alternative immunological pathways such as invariant natural killer T (iNKT) cell or Toll-like receptors (TLR), respectively.

\section{Traditional Protein Carriers}

Five carrier proteins are currently used in licensed conjugate vaccines: diphtheria toxoid (DT), tetanus toxoid (TT), $\mathrm{CRM}_{197}$, Haemophilus protein D (PD), and the outer membrane protein complex of serogroup B meningococcus (OMPC). DT, TT and $\mathrm{CRM}_{197}$ are derived from bacterial toxins detoxified by chemical or genetic means. Diphtheria and tetanus toxoids were initially selected as carriers for Hib conjugate vaccines because of their safety record established over decades of vaccination against tetanus and diphtheria.

OMPC has been used for a Hib conjugate vaccine [19] and a first generation of pneumococcal conjugate vaccines [20]. PD is a $40 \mathrm{kDa}$ cell-surface protein originally derived from non-typeable $H$. influenzae (NTH). It is produced from a recombinant strain of E. coli and has been introduced as a carrier for most of the serotypes in a multivalent pneumococcal conjugate vaccine [21,22]. CRM 197 is a $58 \mathrm{kDa}$ nontoxic mutant of diphtheria toxin with a single Glycine to Glutamic amino acid substitution at position 52 [23], therefore it does not require any chemical detoxification. Its crystal structure has been solved and the molecular aspects at the basis of its non-toxicity elucidated [24]. Nowadays $\mathrm{CRM}_{197}$ can be isolated from the supernatant of cultures of Corynebacterium diphtheriae $\mathrm{C} 7(\beta 197)$ tox $(-)$ or produced by recombinant DNA techniques in heterologous organisms. Full comparability of the proteins obtained by the different manufacturing platforms has been shown [25]. $\mathrm{CRM}_{197}$ has been used extensively as a carrier for licensed Hib, multivalent meningococcal and pneumococcal conjugate vaccines and other vaccines in development [26,27].

\section{New Protein Carriers under Investigation}

Besides the proteins already established as carrier in licensed glycoconjugate vaccines, many other have been tested in preclinical studies and some also in clinical trials; a notable example is the 
recombinant non-toxic form of Pseudomonas aeruginosa exotoxin A ( $r$ EPA) which has been used as carrier for Shigella O-antigens [28], Staphylococcus aureus type 5 and 8 capsular PS [29], and Salmonella Typhi Vi antigen [30,31], and is also widely used for glycoconjugates directly synthesized in E. coli, known as bioconjugates [32-35].

In a recent study, several different recombinant proteins derived from a range of pathogens have been tested in mice as carrier for different fungal and meningococcal glycans, in comparison to $\mathrm{CRM}_{197}$ as bench mark. Some of them, such as the pneumococcal recombinant spr $96 / 2021$ and spr1875, and the Extra intestinal Pathogenic E. coli derived Upec-5211 and Orf3526 proteins, resulted to be potential good carriers [36]. A rationally designed recombinant protein, containing strings of promiscuous human $\mathrm{CD}^{+}{ }^{+}$T-cell epitopes derived from various pathogens including tetanus, influenza virus, Plasmodium falciparum and hepatitis B virus, proved to be a very good carrier for Hib and meningococcal oligosaccharides [37-39]. The recombinant tetanus toxin HC fragment has been used as carrier for synthetic fragments of O-PS of Vibrio cholerae O:1 [40].

As opposed to B cell epitopes that are often of conformational nature, $\mathrm{T}$ cell epitopes of proteins are linear sequences of a minimum of 8-12 amino acids [41] that bind to MHC class II and interact with $\mathrm{T}$ cell receptors on the surface of $\mathrm{CD} 4^{+} \mathrm{T}$ cells. Based on this, many researchers have investigated the possibility to recapitulate the complexity of protein carrier by using synthetic peptides as carrier for carbohydrate antigens. A synthetic peptide representing T-cell epitope of $\mathrm{CRM}_{197}$ has been investigated as carrier for Hib carbohydrate antigen [42]. One of the best known examples is the 13 amino acids non-natural pan DR epitope (PADRE) proposed as universal helper T-lymphocyte and used as carrier for pneumococcal and Shigella antigens [43-45]. A synthetic peptide derived from polio virus was investigated as $\mathrm{T}$ cell epitope in a fully synthetic three-component anti-cancer vaccine containing a tumor associated glycopeptide [46]. Synthetic peptides derived from Candida albicans have been conjugated to a synthetic $\beta$-mannan trisaccharide and elicited in mice specific antibodies against the carbohydrate and peptide moieties. However, mice were immunized using the antigen-pulsed dendritic cell (DC)-based strategy which does not represent a suitable immunization protocol in standard clinical settings [47].

\subsection{Proteins with Dual Role of Carrier and Antigen}

As discussed above, the primary role of the protein carrier in glycoconjugate vaccines is to provide $\mathrm{T}$ cell epitopes that confer a T-dependent character to an otherwise T-independent antigen, such as capsular PS, and make the immune response to the saccharide component similar to the response to proteins. This task is clearly done by the protein carriers present in the currently licensed conjugate vaccines. Interestingly TT, DT and $\mathrm{CRM}_{197}$ based glycoconjugates elicit also antibodies against the respective related toxins (tetanus and diphtheria). PD is the carrier for eight out of 10 PS of the anti-pneumococcal conjugate vaccine PHiD-CV and was selected also with the aim to provide protection against NTHi acute otitis media [48]. The potential to benefit also from the protective antibodies elicited by the protein carrier of glycoconjugates has not been fully exploited until now. There is an increasing interest in investigating the dual role of the protein moiety of glycoconjugate vaccines as carrier a well as protective antigen, as this could simplify the formulation of multicomponent vaccines targeting both carbohydrate and protein virulence factors of a given pathogen. Accordingly, new carrier candidates from different pathogens have been investigated at preclinical level.

A genetically detoxified form of the pneumococcal toxin pneumolysin has been conjugated to pneumococcal PS, eliciting in mice specific antibodies against the related PS and also pneumolysin-specific IgG which neutralized pneumolysin-induced haemolytic activity in vitro [49].

Staphylococcus aureus derived recombinant proteins $\mathrm{Hla}, \mathrm{ClfB}$, and IsdB, conjugated to a synthetic non-acetylated oligosaccharide fragment of poly $N$-acetyl-D-glucosamine (PNAG), induced in mice specific IgG against the carrier protein with functional activity [50]. Wacker et al. showed that Hla bioconjugate with $S$. aureus type 5 capsular PS induced in rabbits and mice specific antibody 
titers against the glycan and the protein moiety both with protective activity [35]. When a fusion of two variants of meningococcal $\mathrm{fHbp}$ was conjugated to meningococcal ACWY PS, immunized mice developed bactericidal titers against the four meningococcus serogroups but also against serogroup $X$, indicating the potential role of the protein carrier as protective antigen too [51]. In a more recent work, Romano et al. conjugated recombinant Clostridium difficile toxin fragments TcdA_B2 and TcdB_GT to PSII surface PS from C. difficile. While only the TcdB_GT conjugate elicited in mice anti-PSII antibody titers comparable to those induced by a CRM 197 -PSII one, both conjugates induced anti-carrier antibodies with toxin neutralizing activity in vitro comparable to the non-conjugated proteins [52].

Group B Streptococcus pili proteins GBS80 and GBS67 have also been proposed as carrier for the capsular PS type II and V, respectively, from the same species $[53,54]$. Since there are three genetically distinct types of pili, namely PI-1, Pl-2a and Pl-2b, and more than five epidemiologically relevant serogroups bearing different capsular PS, conjugates combining protein and glycans can be seen as a means to reduce the vaccine complexity and broaden the coverage.

Simon et al. proposed flagellin as the carrier protein for Salmonella Enteritidis O-antigen, both being virulence factors and protective antigens, with the potential to achieve enhanced protection by the additive effect of anti-O-antigen and anti-flagellin immune responses [55].

\subsection{Nanoparticle Carriers}

Nanoparticle systems have been explored for the display of carbohydrate antigens, combining the multivalent presentation of carbohydrates with the special physico-chemical properties of nano-sized particles.

Keyhole limpet hemocyanin (KLH) (a large multisubunit metalloprotein found in the hemolymph of the giant keyhole limpet, Megathura crenulata), the $\mathrm{Q} \beta$ virus-like particle and OMPC have been used as carrier for tumor antigens, the Alzheimer related peptide amyloid- $\beta$-peptide, and synthetic HIV associated glycans $[7,56]$. KLH has been also employed in the generation of a glycoconjugate targeting B. anthracis spores [57]. Short synthetic S. pneumoniae oligosaccharides have been coupled to Q $\beta$ virus-like particles, eliciting serotype specific, protective and long-lasting IgG antibodies of nanomolar affinity against the target glycans in mice [58]. Recently, Glycoengineered Outer Membrane Vesicles (geOMVs) have been designed for expression of pneumococcal PS, PNAG and F. tularensis O-PS [59-62]. Liposome presenting on the surface a pentadecasaccharide from the lipopolysaccharide of Shigella flexneri, a T cell peptide from influenza hemagglutinin (H307-325) and the immunopotentiator Pam3CAG, induced IgM and IgG titers against the native lipopolysaccharide [63]. In respect to liposome, geOMVs combine antigen presentation and the immunopotentiator effect of the TLR 2 and 4, naturally present on these systems.

$\mathrm{T}$ cell peptides displayed on inorganic nanoparticles have been also tested as carrier for carbohydrate epitopes. Gold nanoparticles presenting a synthetic tetrasaccharide epitope related to pneumococcal type 14 PS, the T-helper ovalbumin 323-339 peptide (OVA323-339), and D-glucose elicited anti-PS IgG antibodies, albeit with lower bactericidal activities than the carbohydrate antigens conjugated to classic carrier proteins [64]. In a follow up work, this platform was used to expose onto the gold core the tetrasaccharide fragment from $S$ pneumoniae serotype 14 and a trisaccharide fragment of serotype 19F (Tri-19F), combined with a T-helper peptide and D-glucose. Mice immunization showed that antibodies were exclusively elicited against the pneumococcal 14 oligosaccharide, probably due to interference with the other glycan [65].

\section{The Chemistry of Protein Carriers}

Carbohydrates can be linked to proteins applying a variety of approaches (Figure 1). Amino acid residues that are most suitable for chemical linkage to sugars are those who are exposed onto the protein surface and whose side chains have reactive functional groups, such as primary amino groups of lysines and carboxylic groups of glutamic or aspartic acid residues. Carboxyl groups of proteins can be conjugated to amino or hydrazido derivatives of sugars by a carbodiimide mediated condensation. 
Lysine amino groups can be coupled to sugars by reaction with their derivatives containing active groups such as succinimido esters or cyano-esters, squarate, or by direct reductive amination $[7,66]$.

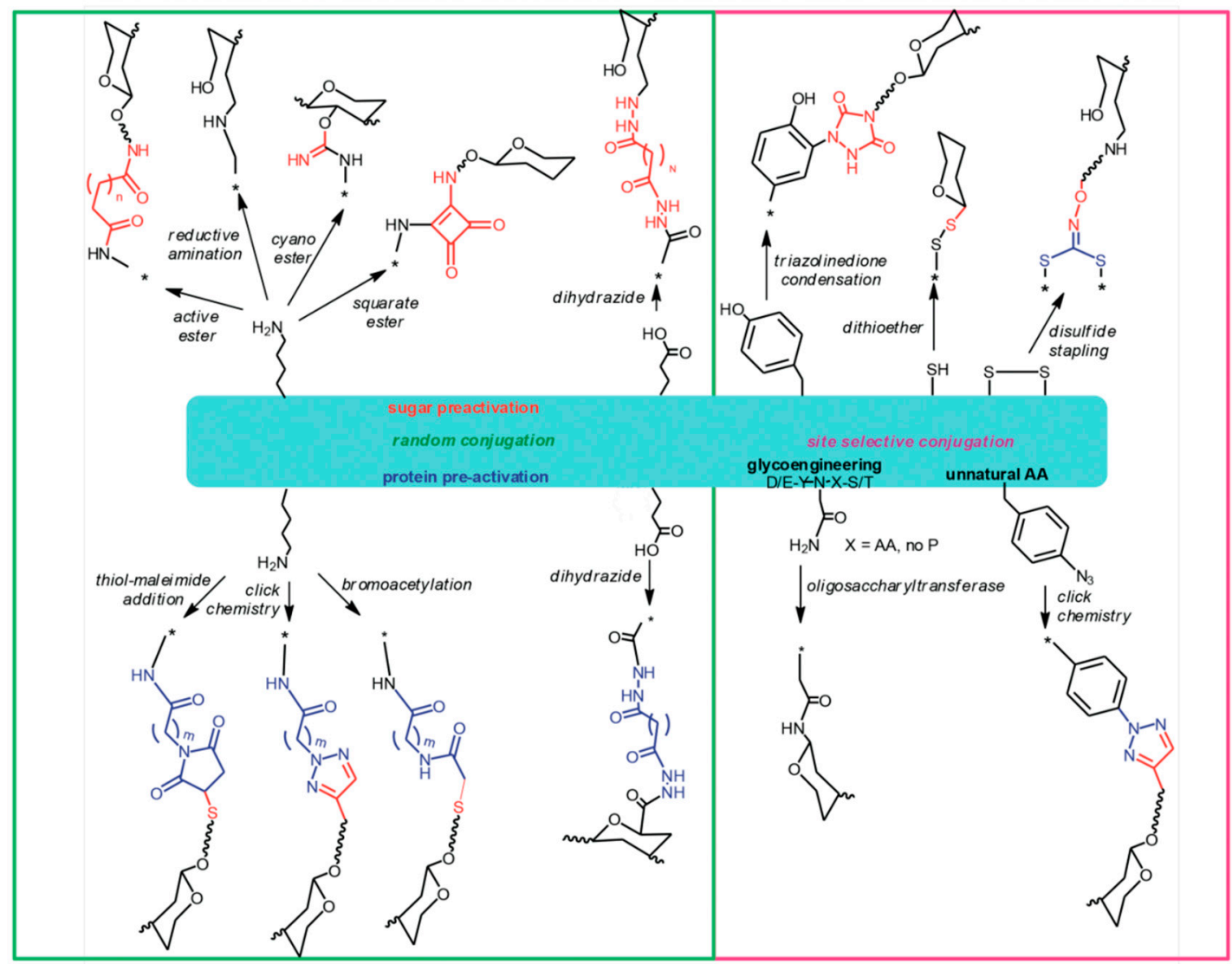

Figure 1. Different ways to attach glycans to protein carriers.

In some cases, the carrier protein is rendered more prone to conjugation, by incorporating spacers offering appropriate functional groups. The protein is typically modified introducing hydrazides, bromoacetyl groups or maleimido groups that react with carboxyl groups, cyano-esters or thiol groups introduced into the carbohydrate, or vice versa introducing sulfhydryl groups to react with bromacetyl or maleimido derivatized PS [67]. Azido groups can also be introduced into proteins for subsequent coupling to glycans derivatized with alkynes, via Copper (I) catalyzed or strain promoted cycloaddition $[54,68,69]$. Generally, linkage of a PS to a carrier protein results invariably in a random display of the carbohydrate onto the protein surface, although some selectivity can be obtained by modulating the carbohydrate to protein stoichiometry [70]. More selectivity has been achieved by targeting other amino acids such as cysteine [71], cysteine disulfide bridges or tyrosines [54,72], and using enzymatic chemistries [69].

A technology that allows selectively placing the glycosylation site on the carrier protein is currently emerging and is known as "bioconjugation". In this approach, the carrier protein engineered to contain one or more $\mathrm{N}$-glycosylation consensus sequences, the glyco-antigen, and an oligosaccharyl transferase are expressed in E. coli cells where the enzyme catalyzes the transfer of the saccharide chain to the asparagine residue of the $\mathrm{N}$-glycosylation site [73-75]. Selective conjugation can be achieved also by introducing into the carrier protein sequence un-natural amino acids bearing functional groups for selective conjugation to glycans via click chemistry [76]. These approaches are of particular interest when the protein has dual role carrier-antigen, assuring the preservation of the key protein epitopes. In a new approach called Multi-Antigen Presenting System (MAPS), the carrier protein is fused to an avidin-like peptide which then couples with strong affinity to biotinylated PS [77]. Recently, PS 
entrapped in cross-linked protein [78], and liposomal encapsulation of PS and proteins [79] have been proposed, based on non-covalent association of PS with protein.

\section{Selection Criteria for Protein Carriers}

As discussed above, the first proteins used as carrier for glycoconjugate vaccines were selected among those already licensed for human vaccines and with a strong track record of safety in conjunction with availability at industrial scale, such as TT and DT. Safety and large scale manufacturability are obviously key selection criteria also for new protein carriers as well as for all new vaccines intended for human use. Any toxic or enzymatic activity should be removed before testing a protein as new carrier. As learned from the history of tetanus and diphtheria toxoids, detoxification can be achieved by chemical treatment with formaldehyde, however this results in extensive modification and heterogeneity that renders more difficult product characterization and might limit the accessibility to some amino acid residues for conjugation.

Whenever possible, genetic detoxification, which selectively intervenes on specific amino acids, is preferred because of the well-defined structure and accessibility of sites for conjugation of the resulting toxoid. Typical examples are $\mathrm{CRM}_{197}$, recombinant $\mathrm{Hla}, r \mathrm{EPA}$ and recombinant pneumolysine cited above.

The suitability of a new protein as carrier is subject to successful preclinical studies confirming the immunogenicity of their conjugates, preferably in comparison to a bench mark carrier.

An important requirement, shared with all antigens, is manufacturability at large scale and according to cGMP. Manufacturability means yields, production cost and quality of the product. A protein that is produced with low yields or whose manufacturing process is not viable at large scale in a cGMP environment, and does not meet the purity requirements (currently at least $>90 \%$ ) has limited probability of success. Quality implies also extensive knowledge of the protein physicochemical and immunological characteristics that are critical to ensure the reproducible production of the glycoconjugate vaccine itself. Protein carriers should contain a sufficient number of exposed amino acids targeted for the selected conjugation process, should be stable and have good solubility in the buffers and concentrations at which conjugation reactions take place. In the case of proteins engineered to insert one or more sites for saccharide attachment, these should be sufficiently surface exposed to allow efficient in vivo glycosylation or in vitro glyco-conjugation.

In the case of the dual role carrier/protective antigen, the protein provides not only $\mathrm{T}$ cell helper epitopes, but also protective B cell epitopes; therefore, carrier selection and vaccine design become more complex and have to meet additional criteria as compared to the classical carrier role. Epitope mapping of the carrier protein to inform the design of the conjugation is critical to avoid loss of protective epitopes on the protein following conjugation.

\section{Characterization of Protein Carriers}

Proteins such as TT and DT are produced and licensed as standalone vaccines and are required to meet the corresponding World Health Organization and pharmacopeia requirements.

Depending on the manufacturing process, DT and TT purified bulk preparations can show different degrees of purity. Typically, the antigenic purity, as determined by the flocculation test (in vitro assay in quality control), should be at least $1500 \mathrm{Lf}$ (limit of flocculation) units/mg protein for DT and 1000 Lf for TT.

Additional characterization may be considered to monitor multimerization or aggregation and purity using size-exclusion chromatography-high performance liquid chromatography (SEC-HPLC) coupled with light scattering detector [80] and sodium dodecyl sulfate-polyacrylamide gel electrophoresis (SDS-PAGE).

For the other protein carriers used in licensed conjugate vaccines (OMPC, $\mathrm{CRM}_{197}$ and PD), analytical characterization and release tests panels have been defined and agreed with Regulatory Agencies during the development of the respective conjugate vaccines. The purity of $\mathrm{CRM}_{197}$ batches is 
expected to be $>90 \%$, and often $>95 \%$, as determined by HPLC, SDS-PAGE or capillary electrophoresis (CE). $\mathrm{CRM}_{197}$ contains an exposed loop of 3 arginine residues that is clipped by proteases present in the culture medium, resulting in a "nicked form" where subunits A and B are still linked through a disulfide bond. The intact polypeptide and the two fragments $\mathrm{A}(\sim 21 \mathrm{kDa})$ and $\mathrm{B}(\sim 38 \mathrm{kDa})$, derived by proteolytic clipping followed by dithiothreitol reduction, can be easily detected by SDS-PAGE in reducing conditions [26]. The manufacturing process is expected to produce $\mathrm{CRM}_{197}$ with a consistently low degree of nicking, generally $<5 \%$ of total $\mathrm{CRM}_{197}$. As mentioned above, $\mathrm{CRM}_{197}$ is now available through recombinant DNA techniques which provide a product highly comparable to that obtained from Corynebacterium diphtheriae platform [25].

The analytical characterization of new protein carriers for glycoconjugate is similar to that of other protein antigens included in vaccines for human use. Most of the potential new carriers are recombinant proteins produced in E. coli. As discussed above, an extensive knowledge of the protein physicochemical and immunological characteristics is important to ensure the reproducible production of the glycoconjugate vaccine itself. A typical initial characterization panel for these antigens is reported in Table 1. A restricted list from this panel might be included into the routine quality control tests for release, once sufficient knowledge of the protein biophysical and immunological characteristics has been acquired and process consistency has been demonstrated. In the case of process changes or transfer technology to a new manufacturing site, such knowledge is used to build a panel of characterization tests and related specifications to ensure comparability with historical batches.

If the carrier is meant to also play the role of antigen, eliciting functional antibodies, it is important to know where the key B epitopes are located in the protein topography to preserve them during the conjugation. Key reagents to map the protein epitopes are monoclonal antibodies, in particular functional ones. Techniques such as X-ray crystallography, Hydrogen Deuterium Exchange Mass Spectrometry (HDX-MS), peptide scanning and phage display can be used to characterize, with different accuracies, the epitopes recognized by a particular monoclonal antibody [81-83]. Surface Plasmon Resonance (SPR) should be used for providing affinity values of the antibody-antigen interaction [83].

\subsection{Characterization of Derivatized Protein Carriers}

As mentioned above, depending on the chemistry chosen, protein carriers might be derivatized before conjugation to PS. The derivatized protein carrier should be characterized with methods suitable to detect and quantify the derivatization degree. The extent of derivatization should be controlled to avoid over-derivatization that might mask potential T cell epitopes of the carrier protein.

For example, the extent of hydrazide derivatization of proteins can be determined using colorimetric assays [84], but also by MS Q-TOF or MALDI-TOF analysis [85]. Thiols groups introduced into protein carrier can be measured by the Ellman's reagent for free thiols [86].

For protein carriers genetically derivatized to insert glycosylation consensus sequences or un-natural amino acids, the incorporations can be confirmed by sequence analyses, amino acid analysis, and mass spectrometry or by in vitro fluorescence labeling techniques [76,87].

Table 2 reports a list of analytical methods for the control of derivatized protein carrier. 
Table 1. Typical characterization panel for protein carriers before conjugation.

\begin{tabular}{|c|c|c|c|c|}
\hline Category & Attribute Measured & Key Techniques & Comment & Impact on Glycoconjugate \\
\hline \multirow{3}{*}{ Purity } & $\%$ of target protein & SDS-PAGE, SEC-HPLC, RP-HPLC & Impact on consistency, potency and safety & Low purity might reflect in poor glycoconjugate purity \\
\hline & Truncated or degradation forms & SEC/RP-HPLC, MS, ELISA & $\begin{array}{l}\text { Product-related substances or impurities } \\
\text { (depending on retention of biological activity) }\end{array}$ & $\begin{array}{l}\text { Heterogeneity of glycoconjugates which might impact } \\
\text { on consistency and immunogenicity }\end{array}$ \\
\hline & Aggregation & SEC-MALS, DLS, MS & $\begin{array}{l}\text { Aggregation is source of heterogeneity: impact } \\
\text { on manufacturing consistency, } \\
\text { immunogenicity, and safety }\end{array}$ & $\begin{array}{l}\text { Heterogeneity of glycoconjugates which might impact } \\
\text { on consistency and immunogenicity }\end{array}$ \\
\hline \multirow{3}{*}{ Impurities } & Host cell residual proteins & WB, ELISA, MS & \multirow{3}{*}{$\begin{array}{l}\text { Poor control of process related impurities } \\
\text { might impact on consistency, potency } \\
\text { and safety }\end{array}$} & \multirow{3}{*}{$\begin{array}{l}\text { Poor control of process related impurities might } \\
\text { impact on consistency, potency and safety }\end{array}$} \\
\hline & DNA & Picogreen, Threshold & & \\
\hline & Chemical residuals & HPLC, Colorimetric assays, NMR & & \\
\hline Contaminants & $\begin{array}{l}\text { Endotoxins, Sterility or } \\
\text { Bioburden }\end{array}$ & $\begin{array}{l}\text { LAL, Microbial count, Compendial } \\
\text { sterility test }\end{array}$ & Impact on safety & Impact on safety \\
\hline \multirow{3}{*}{ Identity and Structure } & Antibody binding & WB, ELISA & Immunochemical identity & $\begin{array}{l}\text { Important if dual role of carrier and antigen is } \\
\text { considered }\end{array}$ \\
\hline & Key Protein B cell Epitopes & $\begin{array}{l}\text { Epitope mapping tools: X-ray, } \\
\text { HDX-MS, SPR }\end{array}$ & Mapping of key functional protein epitopes & $\begin{array}{l}\text { Important to precisely map key protein B cell epitopes } \\
\text { if dual role of carrier and antigen is considered }\end{array}$ \\
\hline & $\begin{array}{l}\text { Primary structure, Intact Mass, } \\
\text { Amino acidic composition }\end{array}$ & MS, Amino acids analysis & $\begin{array}{l}\text { Classical physicochemical protein } \\
\text { identification tests }\end{array}$ & Well defined protein moiety of glycoconjugate \\
\hline \multirow[b]{3}{*}{ Structure } & Secondary structure & $\mathrm{CD}$ & \multirow{2}{*}{$\begin{array}{l}\text { Structure knowledge important if dual role of } \\
\text { carrier and antigen is considered }\end{array}$} & \multirow{2}{*}{$\begin{array}{l}\text { Important to compare structure before and after } \\
\text { conjugation if dual role of carrier and antigen } \\
\text { is considered }\end{array}$} \\
\hline & Tertiary structure & FLR, DSC, X-ray, EM & & \\
\hline & $\begin{array}{l}\text { Lipidation, Deamidation, } \\
N \text {-terminal methionine, } \\
\text { Glycation }\end{array}$ & MS, SDS- PAGE, WB, ELISA, CE & Post-translational modifications & $\begin{array}{l}\text { Lipidation might provide adjuvant effect; } \\
\text { deamidation might results in additional conjugation } \\
\text { sites (depending on the chemistry); glycation might } \\
\text { interfere with carbohydrate analyses on conjugates }\end{array}$ \\
\hline Stability & $\begin{array}{l}\text { Purity, Integrity, Identity, } \\
\text { Sterility/Bioburden }\end{array}$ & $\begin{array}{l}\text { SDS PAGE, SEC-HPLC, RP-HPLC, } \\
\text { SEC-MALS, WB, DLS }\end{array}$ & $\begin{array}{l}\text { Stability protocols at different temperatures are } \\
\text { practices common to all biological products }\end{array}$ & Impact on glycoconjugate stability \\
\hline Toxicity & Safety & In vitro tests, animal studies & Standard for vaccines & Standard for vaccines \\
\hline
\end{tabular}


Table 2. Example of characterization approach for derivatized protein carriers.

\begin{tabular}{|c|c|c|c|c|}
\hline Category & Attribute Measured & Key Techniques & Comment & Impact on Glycoconjugate \\
\hline \multirow[t]{3}{*}{ Structure } & $\begin{array}{l}\text { Extent of chemical } \\
\text { derivatization }\end{array}$ & $\begin{array}{l}\text { MS and/or colorimetric assays } \\
\text { suitable for the kind of derivatization } \\
\text { (e.g., hydrazide, thiol) }\end{array}$ & $\begin{array}{l}\text { Level of chemical derivatization can inform } \\
\text { conjugation stoichiometry. } \\
\text { Can impact on protein folding, protein } \mathrm{T} \text { and } \mathrm{B} \text { cell } \\
\text { epitope preservation and aggregate formation }\end{array}$ & $\begin{array}{l}\text { Level of chemical derivatization dictates } \\
\text { the maximum protein to carbohydrate } \\
\text { ratio, and immunogenicity }\end{array}$ \\
\hline & Site of chemical derivatization & MS & Can impact on protein epitopes & $\begin{array}{l}\text { Informs the conjugate structure and } \\
\text { impact on immunogenicity }\end{array}$ \\
\hline & Genetic derivatization & $\begin{array}{l}\text { DNA Sequence, MS, in vitro } \\
\text { labeling techniques }\end{array}$ & $\begin{array}{l}\text { Glycosylation sequences or un-natural amino } \\
\text { acids amenable for conjugation can be inserted } \\
\text { into the carrier protein }\end{array}$ & $\begin{array}{l}\text { Precisely inform the } \\
\text { glycoconjugate structure }\end{array}$ \\
\hline Purity & Aggregation & $\begin{array}{l}\text { SEC-MALS, DLS, MS, SDS-PAGE } \\
\text { (covalent aggregates) }\end{array}$ & $\begin{array}{l}\text { Chemical derivatization can cause covalent or } \\
\text { non-covalent aggregation with consequent } \\
\text { glycoconjugate heterogeneity }\end{array}$ & $\begin{array}{l}\text { Heterogeneity of glycoconjugates might } \\
\text { impact on consistency and } \\
\text { immunogenicity }\end{array}$ \\
\hline Identity & Antibody binding & WB, ELISA, SPR & Mapping of key functional protein epitopes & $\begin{array}{l}\text { Important to preserve key protein B cell } \\
\text { epitopes during conjugation if dual role } \\
\text { of carrier and antigen is considered }\end{array}$ \\
\hline
\end{tabular}




\subsection{Characterization of the Conjugated Protein}

Following conjugation, the protein carrier is modified at one or more sites. Depending on the coupling strategy, different glycoconjugates configurations are possible: (a) monomeric or limited cross-linked glycoconjugates, where the protein carrier is modified with multiple saccharide chains that have one or more activation sites for conjugation; and (b) cross-linked conjugates where multiple activated saccharide chains and protein molecules couple together creating a cross-linked network.

In the case of monomeric glycoconjugates, from the protein to PS ratio $(w / w)$ and the molecular weights of both protein carrier and glycan, it is possible to calculate the average number of saccharide molecules attached to the protein. When reductive amination was used as chemistry for the Hib conjugate vaccine, a method based on complete removal of the carbohydrate moiety resulted in a novel stable derivative of the lysines previously conjugated, and its quantitative determination by amino acid analysis provided the degree of conjugation independently from the glycan analysis [88].

However, this information does not tell us which amino acids of the protein have been involved in the conjugation reaction.

For a comprehensive characterization of the glycoconjugates and for comparability assessing following process changes or technological transfer to other manufacturing sites, the availability of methods for determining the conjugation profile of the protein carrier is very important. Mass spectrometry is a potent tool for determining the location of the saccharide chains on protein carriers. For long and heterogeneous PS, the peptide mapping procedure can be modified to include a step for carbohydrate moiety removal prior mass spectrometry analysis [89-91].

Table 3 summarizes main assays for protein moiety characterization of glycoconjugate vaccines.

Table 3. Example of characterization panel for the protein moiety of glycoconjugate vaccines (drug substance).

\begin{tabular}{|c|c|c|c|}
\hline Category & Attribute Measured & Technique & Comment \\
\hline $\begin{array}{l}\text { Proof of conjugation } \\
\text { (potency) }\end{array}$ & $\begin{array}{l}\text { Covalent linkage } \\
\text { between protein } \\
\text { and glycans }\end{array}$ & SDS PAGE, WB, MS, SEC-HPLC & $\begin{array}{l}\text { Covalent linkage is the gold } \\
\text { standard for } \\
\text { glycoconjugate vaccines }\end{array}$ \\
\hline Extent of conjugation & $\begin{array}{l}\text { Protein to } \\
\text { Carbohydrate ratio }\end{array}$ & $\begin{array}{l}\text { Protein content in conjunction with } \\
\text { sugar quantification: HPAEC-PAD, } \\
\text { colorimetric assays, Mass Spec }\end{array}$ & $\begin{array}{l}\text { Mass Spec is applicable only to } \\
\text { conjugates with well-defined } \\
\text { synthetic carbohydrates }\end{array}$ \\
\hline Identity & Antibody binding & WB, ELISA, SPR & $\begin{array}{l}\text { Mapping of key functional } \\
\text { protein epitopes }\end{array}$ \\
\hline Identity and Structure & $\begin{array}{l}\text { Key protein B } \\
\text { cell epitope }\end{array}$ & $\begin{array}{l}\text { Epitope mapping tools, X-Ray, } \\
\text { HDX-MS, SPR, in vitro potency } \\
\text { assays }\end{array}$ & $\begin{array}{l}\text { Key protein B cell epitopes should } \\
\text { be preserved if dual role of carrier } \\
\text { and antigen is considered }\end{array}$ \\
\hline Structure & $\begin{array}{l}\text { Location of saccharide } \\
\text { chains }\end{array}$ & MS & $\begin{array}{l}\text { Confirmatory for site selective } \\
\text { conjugation methods and } \\
\text { glycoengineering methods where } \\
\text { attachment sites are predetermined }\end{array}$ \\
\hline Structure & $\begin{array}{l}\text { Secondary and } \\
\text { tertiary structure }\end{array}$ & CD, FLR, DSC & $\begin{array}{l}\text { Secondary structure can be modified } \\
\text { as result of glycoconjugation }\end{array}$ \\
\hline Potency & Free protein & SDS PAGE, SEC-HPLC, CE & $\begin{array}{l}\text { Levels of un-conjugated protein } \\
\text { might interfere with glycoconjugate } \\
\text { immunogenicity }\end{array}$ \\
\hline Purity & $\begin{array}{l}\text { Aggregation and } \\
\text { multimerization }\end{array}$ & SDS PAGE, HPLC, SEC-MALS, DLS & $\begin{array}{l}\text { Heterogeneity of glycoconjugates } \\
\text { might impact on consistency and } \\
\text { immunogenicity }\end{array}$ \\
\hline Stability & $\begin{array}{l}\text { Purity, Integrity, Identity, } \\
\text { Sterility/Bioburden, } \\
\text { Free protein }\end{array}$ & $\begin{array}{l}\text { SEC-HPLC, SEC-MALS, SDS PAGE, } \\
\text { WB }\end{array}$ & $\begin{array}{l}\text { Generally part of the stability } \\
\text { program for the } \\
\text { glycoconjugate antigen }\end{array}$ \\
\hline
\end{tabular}

Does not include tests for the carbohydrate moiety of the glycoconjugates and other standard tests routinely done for vaccines such as process impurities, sterility/bioburden, and LAL. 


\section{Conclusions}

The protein component of glycoconjugate vaccines actively participates in their immunological processing providing $\mathrm{T}$ cell epitopes that are critical for the induction of high avidity antibodies in all classes of age, including infants, and for eliciting a memory response.

Licensed glycoconjugate vaccines mostly use traditional carriers. DT, TT and $\mathrm{CRM}_{197}$ have been used for Hib, pneumococcal and meningococcal conjugate vaccines. Exceptions are constituted by OMPC and PD, used, respectively, by Merck and GSK for their Hib and pneumococcal conjugate vaccines.

From the clinical studies on glycoconjugate vaccines, it is in general difficult to draw conclusions about which protein carrier has the better impact on conjugate vaccine immunogenicity. This is because, besides the carrier, and for a given carbohydrate, there are other parameters that can influence the immunogenicity of glycoconjugate vaccines such as conjugation chemistry, the presence or not of a spacer, saccharide size and degree of conjugation [7].

There is a flowering of new protein carriers under evaluation which is driven by several considerations.

For example, pre-exposure or co-exposure to a certain carrier can lead to reduction of the anti-carbohydrate immune response against glycoconjugate vaccines, via immune interference phenomena called carrier epitope suppression and bystander effect [92]. The use of more and more composite immunization schedules increases the likelihood of immune interference. The investigation on new carriers is driven also by the interest to explore the dual role as carrier and protective antigen that a pathogen related protein can play, thus resulting in a vaccine that, by simultaneous administration of carbohydrate and protein antigens, tackles two different virulence factors of the pathogen. In this case, the extent and location of the saccharide chains on the protein carrier might be relevant in terms of preservation of its key B-cell epitopes. The availability of analytical techniques to map both protein and carbohydrate epitopes become important as well as methods to determine the protein sites that have been conjugated and to assess the impact on protein folding. Site specific conjugation chemistries or glycoengineering, which deliver products with predefined connectivity of the carbohydrate to the protein, are powerful tools to prevent any possible detrimental effect of glycoconjugation on the protein immunogenicity and to simplify the quality controls needed for vaccine release.

Synthetic peptides, either directly conjugated to the glycan or linked to a liposome or a gold nanoparticle core, have been proposed as alternative carriers [42-46]; the biggest challenge for human application is the MHC class II genetic restriction which requires a diversity of T cell epitopes presented by proteins to better address its genetic polymorphism.

Novel carrier systems, in particular nanoparticles, have been recently proposed as alternative to traditional proteins. Presentation of multiple copies of carbohydrate antigen (multivalence), favoring B-cell activation, and in a conformation that resembles that on native bacteria, joint to optimal nanoparticle size for immune stimulation, seem very promising to drive an effective immune response. Among nanoparticles, OMVs combine antigen presentation with intrinsic adjuvant properties [93] and are receiving great attention.

The selection of new protein carrier is guided by a matrix of factors which include manufacturability at industrial scale joint to the appropriate grade of purity to meet the quality requirements needed for clinical testing and for future commercial supply. Ability of the protein to provide T cell help and increase the effectiveness of the conjugated PS is of course fundamental.

Glycoconjugate vaccines can be produced with a variety of methods. The question whether the connection site of the saccharide chain to the protein might impact on the conjugate immunogenicity has no clear answer at the moment. Stefanetti et al. prepared Salmonella Typhimurium O-antigen conjugates, characterized for having one only sugar chain linked to different amino acids on $\mathrm{CRM}_{197}$ and noticed that the induced immune response was different depending on where the saccharide chain was located [69]. In the context of mouse immunization studies with synthetic $\beta$-glucan oligosaccharide- $\mathrm{CRM}_{197}$ conjugates, it has been found that four modified tyrosines can elicit anti-glucan IgG titers not significantly different from those induced by higher levels of glycation at 
lysine of $\mathrm{CRM}_{197}$ [94]. Similar studies should be extended to different PS and carrier proteins, to better understand the impact of conjugation site on immunogenicity.

In terms of number of linkage sites per protein molecule, Pozsgay et al. observed that a high level of protein modification could be needed for optimal immune response of short synthetic Shigella dysenteriae type 1 oligomers, while a lower modification level could be sufficient for longer oligosaccharides, and extensive modification could result in lower response due to masking of $\mathrm{T}$ cell epitopes of the protein [95]. This might suggest the need of a right balance between number and length of saccharide chains attached to the protein carrier and the preservation of the protein $\mathrm{T}$ cell epitopes.

Traditionally, the covalent linkage of PS antigens to the carrier protein is thought to be fundamental to the immunological properties of conjugate vaccines. Recently, there is evidence, in animal models, that covalent attachment to carrier proteins might not be required for conversion of T-independent antigens into T-dependent ones. High affinity non-covalent interaction between carrier and PS such as biotin-avidine based conjugates [77] and different co-presentation systems such as PS entrapped in cross-linked protein matrix [78] and liposomal formulations [79] are under investigation.

These new approaches, together with the use of novel carrier systems $[64,93]$, also appear interesting to further investigate and better understand the mechanism of action of glycoconjugates, supporting the design of improved vaccines. Promising results obtained in animal model need to be confirmed in humans, especially in infants, and the ability of these systems to convert T-independent carbohydrate antigens into T-dependent ones, in comparison to traditional glycoconjugates, needs to be assessed.

Author Contributions: F.M., R.A., and P.C. jointly wrote the review and approved the final version of the manuscript.

Funding: This research received no external funding

Conflicts of Interest: F.M. is an employee of GSK Vaccines Institute for Global Health (GVGH) and is listed as inventor on patents owned by the GSK group of companies. R.A. and P.C. are employees of the GSK group of companies and are listed as inventors on patents owned by the GSK group of companies. P.C. reports ownership of GSK shares.

\section{References}

1. Schneerson, R.; Barrera, O.; Sutton, A.; Robbins, J.B. Preparation, characterization, and immunogenicity of Haemophilus influenzae type b polysaccharide-protein conjugates. J. Exp. Med. 1980, 152, 361-376. [CrossRef] [PubMed]

2. Peltola, H.; Kayhty, H.; Sivonen, A.; Makela, H. Haemophilus influenzae type b capsular polysaccharide vaccine in children: A double-blind field study of 100,000 vaccinees 3 months to 5 years of age in finland. Pediatrics 1977, 60, 730-737. [PubMed]

3. Koskela, M.; Leinonen, M.; Haiva, V.M.; Timonen, M.; Makela, P.H. First and second dose antibody responses to pneumococcal polysaccharide vaccine in infants. Pediatr. Infect. Dis. 1986, 5, 45-50. [CrossRef] [PubMed]

4. Davies, J.A.V. The response of infants to inoculation with type I pneumococcus carbohydrate 1. J. Immunol. 1937, 33, 1-7.

5. Pollard, A.J.; Perrett, K.P.; Beverley, P.C. Maintaining protection against invasive bacteria with protein-polysaccharide conjugate vaccines. Nat. Rev. Immunol. 2009, 9, 213-220. [CrossRef] [PubMed]

6. Kelly, D.F.; Pollard, A.J.; Moxon, E.R. Immunological memory: The role of $\mathrm{b}$ cells in long-term protection against invasive bacterial pathogens. JAMA 2005, 294, 3019-3023. [CrossRef] [PubMed]

7. Costantino, P.; Rappuoli, R.; Berti, F. The design of semi-synthetic and synthetic glycoconjugate vaccines. Expert Opin. Drug Discov. 2011, 6, 1045-1066. [CrossRef] [PubMed]

8. Landsteiner, K. Experiments on anaphylaxis to azoproteins. J. Exp. Med. 1924, 39, 631-637. [CrossRef] [PubMed]

9. Avery, O.T;; Goebel, W.F. Chemo-immunological studies on conjugated carbohydrate-proteins: II. Immunological specificity of synthetic sugar-protein antigens. J. Exp. Med. 1929, 50, 533-550. [CrossRef] [PubMed] 
10. Goebel, W.F.; Avery, O.T. Chemo-immunological studies on conjugated carbohydrate-proteins: IV. The synthesis of thep-aminobenzyl ether of the soluble specific substance of type III pneumococcus and its coupling with protein. J. Exp. Med. 1931, 54, 431-436. [CrossRef] [PubMed]

11. Finland, M.; Sutliff, W.D. Specific antibody response of human subjects to intracutaneous injection of pneumococcus products. J. Exp. Med. 1932, 55, 853-865. [CrossRef] [PubMed]

12. MacLeod, C.M.; Hodges, R.G. Prevention of pneumococcal pneumonia by immunization with specific capsular polysaccharides. J. Exp. Med. 1945, 82, 445-465. [CrossRef] [PubMed]

13. Micoli, F.; Costantino, P.; Adamo, R. Potential targets for next generation anti-microbial glycoconjugate vaccines. FEMS Microbiol. Rev. 2018. [CrossRef] [PubMed]

14. Barrett, D.J. Human immune responses to polysaccharide antigens: An analysis of bacterial polysaccharide vaccines in infants. Adv. Pediatr. 1985, 32, 139-158. [PubMed]

15. Weintraub, A. Immunology of bacterial polysaccharide antigens. Carbohydr. Res. 2003, 338, $2539-2547$. [CrossRef] [PubMed]

16. Avci, F.Y.; Li, X.; Tsuji, M.; Kasper, D.L. A mechanism for glycoconjugate vaccine activation of the adaptive immune system and its implications for vaccine design. Nat. Med. 2011, 17, 1602-1609. [CrossRef] [PubMed]

17. Cavallari, M.; Stallforth, P.; Kalinichenko, A.; Rathwell, D.C.; Gronewold, T.M.; Adibekian, A.; Mori, L.; Landmann, R.; Seeberger, P.H.; De Libero, G. A semisynthetic carbohydrate-lipid vaccine that protects against S. Pneumoniae in mice. Nat. Chem. Biol. 2014, 10, 950-956. [CrossRef] [PubMed]

18. Liao, G.; Zhou, Z.; Suryawanshi, S.; Mondal, M.A.; Guo, Z. Fully synthetic self-adjuvanting alpha-2,9-oligosialic acid based conjugate vaccines against group C meningitis. ACS Cent. Sci. 2016, 2, 210-218. [CrossRef] [PubMed]

19. Donnelly, J.J.; Deck, R.R.; Liu, M.A. Immunogenicity of a Haemophilus influenzae polysaccharide-Neisseria meningitidis outer membrane protein complex conjugate vaccine. J. Immunol. 1990, 145, 3071-3079. [PubMed]

20. Kilpi, T.; Ahman, H.; Jokinen, J.; Lankinen, K.S.; Palmu, A.; Savolainen, H.; Gronholm, M.; Leinonen, M.; Hovi, T.; Eskola, J.; et al. Protective efficacy of a second pneumococcal conjugate vaccine against pneumococcal acute otitis media in infants and children: Randomized, controlled trial of a 7-valent pneumococcal polysaccharide-meningococcal outer membrane protein complex conjugate vaccine in 1666 children. Clin. Infect. Dis. 2003, 37, 1155-1164. [PubMed]

21. Forsgren, A.; Riesbeck, K.; Janson, H. Protein D of Haemophilus influenzae: A protective nontypeable $H$. Influenzae antigen and a carrier for pneumococcal conjugate vaccines. Clin. Infect. Dis. 2008, 46, 726-731. [CrossRef] [PubMed]

22. Prymula, R.; Peeters, P.; Chrobok, V.; Kriz, P.; Novakova, E.; Kaliskova, E.; Kohl, I.; Lommel, P.; Poolman, J.; Prieels, J.-P.; et al. Pneumococcal capsular polysaccharides conjugated to protein D for prevention of acute otitis media caused by both streptococcus pneumoniae and non-typable Haemophilus influenzae: A randomised double-blind efficacy study. Lancet 2006, 367, 740-748. [CrossRef]

23. Giannini, G.; Rappuoli, R.; Ratti, G. The amino-acid sequence of two non-toxic mutants of diphtheria toxin: CRM45 and CRM197. Nucleic Acids Res. 1984, 12, 4063-4069. [CrossRef] [PubMed]

24. Malito, E.E.; Bursulaya, B.B.; Chen, C.C.; Lo Surdo, P.P.; Picchianti, M.M.; Balducci, E.E.; Biancucci, M.M.; Brock, A.A.; Berti, F.F.; Bottomley, M.J.M.; et al. Structural basis for lack of toxicity of the diphtheria toxin mutant CRM197. Proc. Natl. Acad. Sci. USA 2012, 109, 5229-5234. [CrossRef] [PubMed]

25. Hickey, J.M.; Toprani, V.M.; Kaur, K.; Mishra, R.P.N.; Goel, A.; Oganesyan, N.; Lees, A.; Sitrin, R.; Joshi, S.B.; Volkin, D.B. Analytical comparability assessments of five recombinant CRM197 proteins from different manufacturers and expression systems. J. Pharm. Sci. 2018. [CrossRef] [PubMed]

26. Bröker, M.; Costantino, P.; DeTora, L.; McIntosh, E.D.; Rappuoli, R. Biochemical and biological characteristics of cross-reacting material 197 (CRM197), a non-toxic mutant of diphtheria toxin: Use as a conjugation protein in vaccines and other potential clinical applications. Biologicals 2011, 39, 195-204. [CrossRef] [PubMed]

27. Shinefield, H.R. Overview of the development and current use of CRM197 conjugate vaccines for pediatric use. Vaccine 2010, 28, 4335-4339. [CrossRef] [PubMed]

28. Cohen, D.; Ashkenazi, S.; Green, M.S.; Gdalevich, M.; Robin, G.; Slepon, R.; Yavzori, M.; Orr, N.; Block, C.; Ashkenazi, I.; et al. Double-blind vaccine-controlled randomised efficacy trial of an investigational Shigella sonnei conjugate vaccine in young adults. Lancet 1997, 349, 155-159. [CrossRef] 
29. Fattom, A.; Schneerson, R.; Watson, D.C.; Karakawa, W.W.; Fitzgerald, D.; Pastan, I.; Li, X.; Shiloach, J.; Bryla, D.A.; Robbins, J.B. Laboratory and clinical evaluation of conjugate vaccines composed of Staphylococcus aureus type 5 and type 8 capsular polysaccharides bound to Pseudomonas aeruginosa recombinant exoprotein A. Infect. Immun. 1993, 61, 1023-1032. [PubMed]

30. Kossaczka, Z.; Lin, F.Y.; Ho, V.A.; Thuy, N.T.; Van Bay, P.; Thanh, T.C.; Khiem, H.B.; Trach, D.D.; Karpas, A.; Hunt, S.; et al. Safety and immunogenicity of Vi conjugate vaccines for typhoid fever in adults, teenagers, and 2- to 4-year-old children in vietnam. Infect. Immun. 1999, 67, 5806-5810. [PubMed]

31. Szu, S.C.; Stone, A.L.; Robbins, J.D.; Schneerson, R.; Robbins, J.B. Vi capsular polysaccharide-protein conjugates for prevention of typhoid fever. Preparation, characterization, and immunogenicity in laboratory animals. J. Exp. Med. 1987, 166, 1510-1524. [CrossRef] [PubMed]

32. Hatz, C.F.R.; Bally, B.; Rohrer, S.; Steffen, R.; Kramme, S.; Siegrist, C.-A.; Wacker, M.; Alaimo, C.; Fonck, V.G. Safety and immunogenicity of a candidate bioconjugate vaccine against Shigella dysenteriae type 1 administered to healthy adults: A single blind, partially randomized phase I study. Vaccine 2015, 33, 4594-4601. [CrossRef] [PubMed]

33. Riddle, M.S.; Kaminski, R.W.; Di Paolo, C.; Porter, C.K.; Gutierrez, R.L.; Clarkson, K.A.; Weerts, H.E.; Duplessis, C.; Castellano, A.; Alaimo, C.; et al. Safety and immunogenicity of a candidate bioconjugate vaccine against Shigella flexneri $2 \mathrm{a}$ administered to healthy adults: A single-blind, randomized phase I study. Clin. Vaccine Immunol. 2016, 23, 908-917. [CrossRef] [PubMed]

34. Huttner, A.; Hatz, C.; van den Dobbelsteen, G.; Abbanat, D.; Hornacek, A.; Frolich, R.; Dreyer, A.M.; Martin, P.; Davies, T.; Fae, K.; et al. Safety, immunogenicity, and preliminary clinical efficacy of a vaccine against extraintestinal pathogenic Escherichia coli in women with a history of recurrent urinary tract infection: A randomised, single-blind, placebo-controlled phase $1 \mathrm{~b}$ trial. Lancet Infect. Dis. 2017, 17, 528-537. [CrossRef]

35. Wacker, M.; Wang, L.; Kowarik, M.; Dowd, M.; Lipowsky, G.; Faridmoayer, A.; Shields, K.; Park, S.; Alaimo, C.; Kelley, K.A.; et al. Prevention of Staphylococcus aureus infections by glycoprotein vaccines synthesized in Escherichia coli. J. Infect. Dis. 2014, 209, 1551-1561. [CrossRef] [PubMed]

36. Tontini, M.; Romano, M.R.; Proietti, D.; Balducci, E.; Micoli, F.; Balocchi, C.; Santini, L.; Masignani, V.; Berti, F.; Costantino, P. Preclinical studies on new proteins as carrier for glycoconjugate vaccines. Vaccine 2016, 34, 4235-4242. [CrossRef] [PubMed]

37. Baraldo, K.; Mori, E.; Bartoloni, A.; Norelli, F.; Grandi, G.; Rappuoli, R.; Finco, O.; Del Giudice, G. Combined conjugate vaccines: Enhanced immunogenicity with the N19 polyepitope as a carrier protein. Infect. Immun. 2005, 73, 5835-5841. [CrossRef] [PubMed]

38. Baraldo, K.; Mori, E.; Bartoloni, A.; Petracca, R.; Giannozzi, A.; Norelli, F.; Rappuoli, R.; Grandi, G.; Del Giudice, G. N19 polyepitope as a carrier for enhanced immunogenicity and protective efficacy of meningococcal conjugate vaccines. Infect. Immun. 2004, 72, 4884-4887. [CrossRef] [PubMed]

39. Falugi, F.; Petracca, R.; Mariani, M.; Luzzi, E.; Mancianti, S.; Carinci, V.; Melli, M.L.; Finco, O.; Wack, A.; Di Tommaso, A.; et al. Rationally designed strings of promiscuous CD4(+) T cell epitopes provide help to Haemophilus influenzae type b oligosaccharide: A model for new conjugate vaccines. Eur. J. Immunol. 2001, 31, 3816-3824. [CrossRef]

40. Bongat, A.F.G.; Saksena, R.; Adamo, R.; Fujimoto, Y.; Shiokawa, Z.; Peterson, D.C.; Fukase, K.; Vann, W.F.; Kováč, P. Multimeric bivalent immunogens from recombinant tetanus toxin Hc fragment, synthetic hexasaccharides, and a glycopeptide adjuvant. Glycoconj. J. 2010, 27, 69-77. [CrossRef] [PubMed]

41. Rothbard, J.B.; Taylor, W.R. A sequence pattern common to T cell epitopes. EMBO J. 1988, 7, $93-100$. [PubMed]

42. Bixler, G.S., Jr.; Eby, R.; Dermody, K.M.; Woods, R.M.; Seid, R.C.; Pillai, S. Synthetic peptide representing a T-cell epitope of CRM197 substitutes as carrier molecule in a Haemophilus influenzae type b (Hib) conjugate vaccine. Adv. Exp. Med. Biol. 1989, 251, 175-180. [PubMed]

43. Alexander, J.; del Guercio, M.F.; Maewal, A.; Qiao, L.; Fikes, J.; Chesnut, R.W.; Paulson, J.; Bundle, D.R.; DeFrees, S.; Sette, A. Linear padre T helper epitope and carbohydrate B cell epitope conjugates induce specific high titer IgG antibody responses. J. Immunol. 2000, 164, 1625-1633. [CrossRef] [PubMed]

44. Alexander, J.; del Guercio, M.F.; Frame, B.; Maewal, A.; Sette, A.; Nahm, M.H.; Newman, M.J. Development of experimental carbohydrate-conjugate vaccines composed of Streptococcus pneumoniae capsular polysaccharides and the universal helper T-lymphocyte epitope (PADRE). Vaccine 2004, 22, 2362-2367. [CrossRef] [PubMed] 
45. Belot, F.; Guerreiro, C.; Baleux, F.; Mulard, L.A. Synthesis of two linear PADRE conjugates bearing a deca- or pentadecasaccharide B epitope as potential synthetic vaccines against Shigella flexneri serotype 2a infection. Chemistry 2005, 11, 1625-1635. [CrossRef] [PubMed]

46. Ingale, S.; Wolfert, M.A.; Gaekwad, J.; Buskas, T.; Boons, G.J. Robust immune responses elicited by a fully synthetic three-component vaccine. Nat. Chem. Biol. 2007, 3, 663-667. [CrossRef] [PubMed]

47. Xin, H.; Dziadek, S.; Bundle, D.R.; Cutler, J.E. Synthetic glycopeptide vaccines combining $\beta$-mannan and peptide epitopes induce protection against candidiasis. Proc. Natl. Acad. Sci. USA 2008, 105, 13526-13531. [CrossRef] [PubMed]

48. Broker, M.; Berti, F.; Schneider, J.; Vojtek, I. Polysaccharide conjugate vaccine protein carriers as a "neglected valency"-Potential and limitations. Vaccine 2017, 35, 3286-3294. [CrossRef] [PubMed]

49. Michon, F.; Fusco, P.C.; Minetti, C.A.; Laude-Sharp, M.; Uitz, C.; Huang, C.H.; D'Ambra, A.J.; Moore, S.; Remeta, D.P.; Heron, I.; et al. Multivalent pneumococcal capsular polysaccharide conjugate vaccines employing genetically detoxified pneumolysin as a carrier protein. Vaccine 1998, 16, 1732-1741. [CrossRef]

50. Pozzi, C.; Wilk, K.; Lee, J.C.; Gening, M.; Nifantiev, N.; Pier, G.B. Opsonic and protective properties of antibodies raised to conjugate vaccines targeting six Staphylococcus aureus antigens. PLoS ONE 2012, 7, e46648. [CrossRef] [PubMed]

51. Pinto, V.B.; Burden, R.; Wagner, A.; Moran, E.E.; Lee, C.H. The development of an experimental multiple serogroups vaccine for Neisseria meningitidis. PLoS ONE 2013, 8, e79304. [CrossRef] [PubMed]

52. Romano, M.; Leuzzi, R.; Cappelletti, E.; Tontini, M.; Nilo, A.; Proietti, D.; Berti, F.; Costantino, P.; Adamo, R.; Scarselli, M. Recombinant Clostridium difficile toxin fragments as carrier protein for PSII surface polysaccharide preserve their neutralizing activity. Toxins 2014, 6, 1385-1396. [CrossRef] [PubMed]

53. Nilo, A.; Morelli, L.; Passalacqua, I.; Brogioni, B.; Allan, M.; Carboni, F.; Pezzicoli, A.; Zerbini, F.; Maione, D.; Fabbrini, M.; et al. Anti-group B Streptococcus glycan-conjugate vaccines using pilus protein GBS80 as carrier and antigen: Comparing lysine and tyrosine-directed conjugation. ACS Chem. Biol. 2015, 10, 1737-1746. [CrossRef] [PubMed]

54. Nilo, A.; Passalacqua, I.; Fabbrini, M.; Allan, M.; Usera, A.; Carboni, F.; Brogioni, B.; Pezzicoli, A.; Cobb, J.; Romano, M.R.; et al. Exploring the effect of conjugation site and chemistry on the immunogenicity of an anti-group B Streptococcus glycoconjugate vaccine based on GBS67 pilus protein and type V polysaccharide. Bioconjug. Chem. 2015, 26, 1839-1849. [CrossRef] [PubMed]

55. Simon, R.; Tennant, S.M.; Wang, J.Y.; Schmidlein, P.J.; Lees, A.; Ernst, R.K.; Pasetti, M.F.; Galen, J.E.; Levine, M.M. Salmonella enterica serovar enteritidis core o polysaccharide conjugated to H:g,m flagellin as a candidate vaccine for protection against invasive infection with S. Enteritidis. Infect. Immun. 2011, 79, 4240-4249. [CrossRef] [PubMed]

56. Wang, L.-X. Synthetic carbohydrate antigens for HIV vaccine design. Curr. Opin. Chem. Biol. 2013, 17, 997-1005. [CrossRef] [PubMed]

57. Tamborrini, M.; Werz, D.B.; Frey, J.; Pluschke, G.; Seeberger, P.H. Anti-carbohydrate antibodies for the detection of Anthrax spores. Angew. Chem. Int. Ed. Engl. 2006, 45, 6581-6582. [CrossRef] [PubMed]

58. Polonskaya, Z.; Deng, S.; Sarkar, A.; Kain, L.; Comellas-Aragones, M.; McKay, C.S.; Kaczanowska, K.; Holt, M.; McBride, R.; Palomo, V.; et al. T cells control the generation of nanomolar-affinity anti-glycan antibodies. J. Clin. Investig. 2017, 127, 1491-1504. [CrossRef] [PubMed]

59. Price, N.L.; Goyette-Desjardins, G.; Nothaft, H.; Valguarnera, E.; Szymanski, C.M.; Segura, M.; Feldman, M.F. Glycoengineered Outer Membrane Vesicles: A novel platform for bacterial vaccines. Sci. Rep. 2016, 6, 24931. [CrossRef] [PubMed]

60. Chen, L.; Valentine, J.L.; Huang, C.J.; Endicott, C.E.; Moeller, T.D.; Rasmussen, J.A.; Fletcher, J.R.; Boll, J.M.; Rosenthal, J.A.; Dobruchowska, J.; et al. Outer Membrane Vesicles displaying engineered glycotopes elicit protective antibodies. Proc. Natl. Acad. Sci. USA 2016, 113, E3609-E3618. [CrossRef] [PubMed]

61. Stevenson, T.C.; Cywes-Bentley, C.; Moeller, T.D.; Weyant, K.B.; Putnam, D.; Chang, Y.F.; Jones, B.D.; Pier, G.B.; DeLisa, M.P. Immunization with Outer Membrane Vesicles displaying conserved surface polysaccharide antigen elicits broadly antimicrobial antibodies. Proc. Natl. Acad. Sci. USA 2018, 115, E3106-E3115. [CrossRef] [PubMed]

62. Valguarnera, E.; Feldman, M.F. Glycoengineered Outer Membrane Vesicles as a platform for vaccine development. Methods Enzymol. 2017, 597, 285-310. [PubMed] 
63. Said Hassane, F.; Phalipon, A.; Tanguy, M.; Guerreiro, C.; Belot, F.; Frisch, B.; Mulard, L.A.; Schuber, F. Rational design and immunogenicity of liposome-based diepitope constructs: Application to synthetic oligosaccharides mimicking the Shigella flexneri 2a o-antigen. Vaccine 2009, 27, 5419-5426. [CrossRef] [PubMed]

64. Safari, D.; Marradi, M.; Chiodo, F.; Th Dekker, H.A.; Shan, Y.; Adamo, R.; Oscarson, S.; Rijkers, G.T.; Lahmann, M.; Kamerling, J.P.; et al. Gold nanoparticles as carriers for a synthetic Streptococcus pneumoniae type 14 conjugate vaccine. Nanomedicine 2012, 7, 651-662. [CrossRef] [PubMed]

65. Vetro, M.; Safari, D.; Fallarini, S.; Salsabila, K.; Lahmann, M.; Penadés, S.; Lay, L.; Marradi, M.; Compostella, F. Preparation and immunogenicity of gold glyco-nanoparticles as antipneumococcal vaccine model. Nanomedicine 2017, 12, 13-23. [CrossRef] [PubMed]

66. Xu, P.; Kelly, M.; Vann, W.F.; Qadri, F.; Ryan, E.T.; Kovac, P. Conjugate vaccines from bacterial antigens by squaric acid chemistry: A closer look. ChemBioChem 2017, 18, 799-815. [CrossRef] [PubMed]

67. Marburg, S.; Jorn, D.; Tolman, R.L.; Arison, B.; McCauley, J.; Kinskern, P.J.; Hagopian, A.; Vella, P.P. Bimolecular chemistry of macromolecules: Synthesis of bacterial polysaccharide conjugates with Neissseria meningitis membrane protein. J. Am. Chem. Soc. 1986, 108, 5282-5287. [CrossRef]

68. Lipinski, T.; Luu, T.; Kitov, P.I.; Szpacenko, A.; Bundle, D.R. A structurally diversified linker enhances the immune response to a small carbohydrate hapten. Glycoconj. J. 2011, 28, 149-164. [CrossRef] [PubMed]

69. Stefanetti, G.; Hu, Q.Y.; Usera, A.; Robinson, Z.; Allan, M.; Singh, A.; Imase, H.; Cobb, J.; Zhai, H.; Quinn, D.; et al. Sugar-protein connectivity impacts on the immunogenicity of site-selective Salmonella O-antigen glycoconjugate vaccines. Angew. Chem. Int. Ed. Engl. 2015, 54, 13198-13203. [CrossRef] [PubMed]

70. Crotti, S.; Zhai, H.; Zhou, J.; Allan, M.; Proietti, D.; Pansegrau, W.; Hu, Q.-Y.; Berti, F.; Adamo, R. Defined conjugation of glycans to the lysines of $\mathrm{CRM}_{197}$ guided by their reactivity mapping. ChemBioChem 2014, 15, 836-843. [CrossRef] [PubMed]

71. Grayson, E.J.; Bernardes, G.J.; Chalker, J.M.; Boutureira, O.; Koeppe, J.R.; Davis, B.G. A coordinated synthesis and conjugation strategy for the preparation of homogeneous glycoconjugate vaccine candidates. Angew. Chem. Int. Ed. Engl. 2011, 50, 4127-4132. [CrossRef] [PubMed]

72. Hu, Q.-Y.; Berti, F.; Adamo, R. Towards the next generation of biomedicines by site-selective conjugation. Chem. Soc. Rev. 2016, 45, 1691-1719. [CrossRef] [PubMed]

73. Kowarik, M.; Young, N.M.; Numao, S.; Schulz, B.L.; Hug, I.; Callewaert, N.; Mills, D.C.; Watson, D.C.; Hernandez, M.; Kelly, J.F.; et al. Definition of the bacterial N-glycosylation site consensus sequence. EMBO J. 2006, 25, 1957-1966. [CrossRef] [PubMed]

74. Feldman, M.F.; Wacker, M.; Hernandez, M.; Hitchen, P.G.; Marolda, C.L.; Kowarik, M.; Morris, H.R.; Dell, A.; Valvano, M.A.; Aebi, M. Engineering N-linked protein glycosylation with diverse o antigen lipopolysaccharide structures in Escherichia coli. Proc. Natl. Acad. Sci. USA 2005, 102, 3016-3021. [CrossRef] [PubMed]

75. Ihssen, J.; Kowarik, M.; Dilettoso, S.; Tanner, C.; Wacker, M.; Thöny-Meyer, L. Production of glycoprotein vaccines in Escherichia coli. Microb. Cell Fact. 2010, 9, 61. [CrossRef] [PubMed]

76. Kapoor, N.; Vanjak, I.; Rozzelle, J.; Berges, A.; Chan, W.; Yin, G.; Tran, C.; Sato, A.K.; Steiner, A.R.; Pham, T.P.; et al. Malaria derived glycosylphosphatidylinositol anchor enhances anti-Pfs25 functional antibodies that block malaria transmission. Biochemistry 2018, 57, 516-519. [CrossRef] [PubMed]

77. Zhang, F.; Lu, Y.J.; Malley, R. Multiple antigen-presenting system (MAPS) to induce comprehensive B- and T-cell immunity. Proc. Natl. Acad. Sci. USA 2013, 110, 13564-13569. [CrossRef] [PubMed]

78. Thanawastien, A.; Cartee, R.T.; Griffin, I.; Thomas, J.; Killeen, K.P.; Mekalanos, J.J. Conjugate-like immunogens produced as protein capsular matrix vaccines. Proc. Natl. Acad. Sci. USA 2015, 112, E1143-E1151. [CrossRef] [PubMed]

79. Jones, C.H.; Zhang, G.; Nayerhoda, R.; Beitelshees, M.; Hill, A.; Rostami, P.; Li, Y.; Davidson, B.A.; Knight, P., 3rd; Pfeifer, B.A. Comprehensive vaccine design for commensal disease progression. Sci. Adv. 2017, 3, e1701797. [CrossRef] [PubMed]

80. Frech, C.; Hilbert, A.K.; Hartmann, G.; Mayer, K.; Sauer, T.; Bolgiano, B. Physicochemical analysis of purified diphtheria toxoids: Is toxoided then purified the same as purified then toxoided? Dev. Biol. 2000, 103, 205-215. 
81. Donnarumma, D.; Faleri, A.; Costantino, P.; Rappuoli, R.; Norais, N. The role of structural proteomics in vaccine development: Recent advances and future prospects. Expert Rev. Proteom. 2016, 13, 55-68. [CrossRef] [PubMed]

82. Malito, E.; Carfi, A.; Bottomley, M. Protein crystallography in vaccine research and development. Int. J. Mol. Sci. 2015, 16, 13106-13140. [CrossRef] [PubMed]

83. Malito, E.; Faleri, A.; Lo Surdo, P.; Veggi, D.; Maruggi, G.; Grassi, E.; Cartocci, E.; Bertoldi, I.; Genovese, A.; Santini, L.; et al. Defining a protective epitope on factor $\mathrm{H}$ binding protein, a key meningococcal virulence factor and vaccine antigen. Proc. Natl. Acad. Sci. USA 2013, 110, 3304-3309. [CrossRef] [PubMed]

84. Qi, X.Y.; Keyhani, N.O.; Lee, Y.C. Spectrophotometric determination of hydrazine, hydrazides, and their mixtures with trinitrobenzenesulfonic acid. Anal. Biochem. 1988, 175, 139-144. [CrossRef]

85. Micoli, F.; Rondini, S.; Pisoni, I.; Proietti, D.; Berti, F.; Costantino, P.; Rappuoli, R.; Szu, S.; Saul, A.; Martin, L.B. $\mathrm{Vi}_{-} \mathrm{CRM}_{197}$ as a new conjugate vaccine against Salmonella typhi. Vaccine 2011, 29, 712-720. [CrossRef] [PubMed]

86. Ellman, G.L. Tissue sulfhydryl groups. Arch. Biochem. Biophys. 1959, 82, 70-77. [CrossRef]

87. Kiick, K.L.; Saxon, E.; Tirrell, D.A.; Bertozzi, C.R. Incorporation of azides into recombinant proteins for chemoselective modification by the staudinger ligation. Proc. Natl. Acad. Sci. USA 2002, 99, 19-24. [CrossRef] [PubMed]

88. Seid, R.C.; Boykins, R.A.; Liu, D.F.; Kimbrough, K.W.; Hsieh, C.L.; Eby, R. Chemical evidence for covalent linkages of a semi-synthetic glycoconjugate vaccine for Haemophilus influenzae type b disease. Glycoconj. J. 1989, 6, 489-498. [CrossRef] [PubMed]

89. Barazzone, G.C.; Pinto, V.; Donnarumma, D.; Tanizaki, M.M.; Norais, N.; Berti, F. Identification of glycosylated regions in pneumococcal PspA conjugated to serotype 6B capsular polysaccharide. Glycoconj. J. 2014, 31, 259-269. [CrossRef] [PubMed]

90. Bardotti, A.; Averani, G.; Berti, F.; Berti, S.; Carinci, V.; D’Ascenzi, S.; Fabbri, B.; Giannini, S.; Giannozzi, A.; Magagnoli, C.; et al. Physicochemical characterisation of glycoconjugate vaccines for prevention of meningococcal diseases. Vaccine 2008, 26, 2284-2296. [CrossRef] [PubMed]

91. De Benedetto, G.; Salvini, L.; Gotta, S.; Cescutti, P.; Micoli, F. Investigation on sugar-protein connectivity in Salmonella O-antigen glycoconjugate vaccines. Bioconjug. Chem. 2018, 29, 1736-1747. [CrossRef] [PubMed]

92. Dagan, R.; Poolman, J.; Siegrist, C. Glycoconjugate vaccines and immune interference: A review. Vaccine 2010, 28, 5513-5524. [CrossRef] [PubMed]

93. Gerritzen, M.J.H.; Martens, D.E.; Wijffels, R.H.; van der Pol, L.; Stork, M. Bioengineering bacterial outer membrane vesicles as vaccine platform. Biotechnol. Adv. 2017, 35, 565-574. [CrossRef] [PubMed]

94. Adamo, R.; Hu, Q.-Y.; Torosantucci, A.; Crotti, S.; Brogioni, G.; Allan, M.; Chiani, P.; Bromuro, C.; Quinn, D.; Tontini, M.; et al. Deciphering the structure-immunogenicity relationship of anti-Candida glycoconjugate vaccines. Chem. Sci. 2014, 5, 4302-4311. [CrossRef]

95. Pozsgay, V.; Chu, C.; Pannell, L.; Wolfe, J.; Robbins, J.B.; Schneerson, R. Protein conjugates of synthetic saccharides elicit higher levels of serum IgG lipopolysaccharide antibodies in mice than do those of the O-specific polysaccharide from Shigella dysenteriae type 1. Proc. Natl. Acad. Sci. USA 1999, 96, 5194-5197. [CrossRef] [PubMed]

(C) 2018 by the authors. Licensee MDPI, Basel, Switzerland. This article is an open access article distributed under the terms and conditions of the Creative Commons Attribution (CC BY) license (http://creativecommons.org/licenses/by/4.0/). 